\title{
PENGARUH PEMBERIAN UMPAN BALIK DAN GENDER TERHADAP PENINGKATAN SELF ESTEEM SISWA SMP
}

\author{
Yusnita Pusparagen 1 , \\ Adang Suherman ${ }^{2}$ \\ (Mahasiswi Sekolah Pasca-sarjana POR UPI)
}

\begin{abstract}
The purpose of this study are: (1) To determine the effect of giving feedback on increasing self esteem on junior high school students. (2) To find out the effect of gender on increasing self esteem for junior high school students, and (3) to find out the interaction between giving feedback and gender to increasing self esteem for junior high school students. The method used is an experimental method with $2 \times 2$ factorial design. The population is all students of class VII UPI Lab Middle School amounting to 175 students, with a sample of 2 classes with a total of 57 students, the sampling technique is using cluster random sampling. The instrument used was the adoption of the Self Esteem Rating Scale (SERS) developed by Nugent \& Thomas (1993). Analysis using SPSS 17 using ANOVA technique. Data processing results show that: (1) Feedback has a significant effect on increasing self esteem of junior high school students. (2) Gender does not have a significant influence on increasing self esteem of junior high school students. (3) There is no influence of interaction between feedback and gender on increasing self esteem of junior high school students.
\end{abstract}

Keywords: Feedback, Gender, Self Esteem

\begin{abstract}
ABSTRAK
Tujuan dari penelitian ini adalah: (1) Untuk mengetahui pengaruh pemberian umpan balik terhadap peningkatan self esteem pada peserta didik SMP. (2) Untuk mengetahui pengaruh gender terhadap peningkatan self esteem pada peserta didik SMP, dan (3) Untuk mengetahui interaksi antara pemberian umpan balik dan gender terhadap peningkatan self esteem pada peserta didik SMP. Metode yang digunakan adalah metode eksperimen dengan desain faktorial 2x2. Populasi adalah seluruh siswa SMP Lab UPI kelas VII yang berjumlah 175 peserta didik, dengan sampel sebanyak 2 kelas dengan jumlah 57 peserta didik, tekhnik sampling yaitu menggunakan cluster random sampling. Instrumen yang digunakan merupakan adopsi dari Self Esteem Rating Scale (SERS) yang dikembangkan oleh Nugent \& Thomas (1993). Analisis dengan menggunakan SPSS 17 menggunakan teknik ANOVA. Hasil pengolahan data menunjukan bahwa: (1) Feedback memiliki pengaruh yang
\end{abstract}


signifikan terhadap peningkatan self esteem peserta didik SMP. (2) Gender tidak memiliki pengaruh yang signifikan terhadap peningkatan self esteem peserta didik SMP. (3) Tidak terdapat pengaruh interaksi antara feedback dan gender terhadap peningkatan self esteem peserta didik SMP.

Kata kunci : Umpan balik, Gender, Self Esteem

\section{A. Pendahuluan}

Program pembelajaran pendidikan jasmani memiliki tujuan dan fungsi untuk menumbuhkembangkan seluruh domain (aspek) yang dimiliki oleh peserta didik. Domain tersebut mencakup ranah psikomotor, kognitif, dan afektif. Pada aspek psikomotor terlihat jelas untuk diamati karena pendidikan jasmani adalah pendidikan melalui aktivitas fisik (jasmani) yang bertujuan mengembangkan kemampuan gerak peserta didik. Pada aspek kognitif, program pendidikan jasmani berupaya mengembangkan kemampuan berfikir kritis dan daya nalar melalui berbagai konsep yang terkait dengan pemahaman tentang rangkaian gerak, kemampuan menganalisa gerakan, dan pemahaman konsep pola hidup sehat.
Melalui program pendidikan jasmani (penjas) dikembangkan pula aspek afektif yang terkait dengan perkembangan sikap dan emosional. Siswa diarahkan untuk memiliki kemampuan mengendalikan emosi, memiliki konsep diri yang positif, memiliki kemampuan berinteraksi secara efektif dengan orang lain, mampu menghormati dan menghargai kemampuan orang lain, dan memiliki kebanggaan serta percaya diri (self esteem) terhadap kemampuan yang dimilikinya (Lutan, 2001, hlm. 34-35).

Self esteem diartikan dalam istilah percaya diri meskipun tidak sepenuhnya menggambarkan makna yang sesungguhnya. Lutan (2003, hlm. 3) memaparkan bahwa "self esteem adalah penerimaan diri sendiri, oleh diri sendiri berkaitan bahwa kita pantas, berharga, mampu dan berguna tak peduli 
dengan apa pun yang sudah, sedang atau bakal terjadi. Tumbuhnya perasaan aku bisa dan aku berharga merupakan inti dari pengertian self esteem". Hal yang serupa diungkapkan dalam sebuah situs "Kidshealth" (2006) yang menyatakan bahwa "Self esteem is the collection of beliefs or feeling that we have about ourselves, or our "self-perception." How we define ourselfes influences or motivations, attitudes, and behavioras and affects our emotional adjustment". Maksudnya adalah self esteem merupakan kumpulan dari kepercayaan atau perasaan tentang diri kita atau persepsi kita terhadap diri sendiri tentang motivasi, sikap, perilaku, dan penyesuaian emosi yang mempengaruhi kita.

Situs KidsHealts (2006) memaparkan mengenai dua jenis self esteem yaitu Unhealty Self esteem dan Healthy Self esteem. Self esteem yang rendah atau tidak sehat pada anak ditandai dengan tidak adanya keinginan melakukan sesuatu hal yang baru, anak selalu berkata negatif atas kemampuan yang dimilikinya misalnya "Saya bodoh!", "Saya tidak pernah belajar dengan baik". Ciri yang lainnya adalah anak tidak memiliki toleransi, frustasi, dan pesimis. Sedangkan pada anak yang memiliki self esteem yang sehat ditandai dengan senang memelihara hubungan dengan yang lain, aktif dalam kelompoknya, menyenangkan dalam berhubungan baik, mampu menemukan solusi ketika peluang menipis, memahami kekuatan dan kelemahannya serta memiliki sikap optimis.

Self esteem dapat tercermin dari cara seseorang berperilaku dan berbuat. Self esteem berkenaan dengan kemampuan untuk memahami apa yang sedang dan telah diperbuat, dan berkenaan pula dengan penetapan tujuan yang harus dicapai. Dalam konteks pembelajaran pendidikan jasmani, kita dapat mengamati self esteem yang dimiliki oleh para peserta didik. Peserta didik yang memiliki self esteem tinggi atau self esteem 


\section{Didaktik : Jurnal Pendidikan Guru Sekolah Dasar, ISSN : 24775673 \\ Sekolah Tinggi Keguruan dan IImu Pendidikan Subang Volume IV Nomor 1, Juli 2018}

yang sehat pada umumnya memiliki kepercayaan diri dan keyakinan yang tinggi pula untuk dapat melakukan tugas gerak yang diinstruksikan guru. Mereka biasanya bersungguh-sungguh dalam melakukan aktivitas jasmani dan selalu berupaya memperbaiki kekurangan dan terus berlatih meningkatkan kemampuannya. Ciri ini akan sangat berbeda dengan peserta didik yang rendah self esteemnya atau yang tidak memiliki self esteem. Umumnya mereka enggan atau bermalas-malasan melakukan tugas gerak karena merasa khawatir atau tidak percaya terhadap kemampuan yang dimilikinya, tidak bekerja keras memperbaiki kekurangannya dan merasa cukup dengan apa yang sudah dilakukannya. Sebuah penelitian yang dilakukan oleh Allegrante (2010) menyebutkan bahwa "Self esteem sangat berhubungan erat dengan kesehatan fisik dan mental". Hal ini berhubungan dengan hasil penelitian yang dilakukan oleh Koka (2006) bahwa "Ancaman dengan stabilitas tinggi dari rendahnya umpan balik yang diberikan oleh guru sangat dirasakan pada pendidikan jasmani". Dari hasil penelitian tersebut di atas dapat terlihat bahwa guru pendidikan jasmani jarang sekali memberikan umpan balik sehingga tujuan dari pelajaran pendidikan jasmani sulit tercapai, sedangkan hasil penelitian sebelumnya menjelaskan bahwa self esteem sangat berhubungan erat dengan kesehatan fisik.

Peristiwa seperti itu akan menjadi hambatan bagi terciptanya lingkungan belajar penjas yang kondusif. Sudah menjadi kewajiban guru penjas untuk mampu menyajikan program pengajaran penjas yang baik yang dapat mengatasi peserta didik yang tidak memiliki self esteem atau taraf self esteemnya masih rendah. "Guru atau pelatih merupakan sumber penting dalam mengembangkan self esteem siswa atau atlet, bahkan sebaliknya guru berpotensi menghancurkan self esteem siswa" (Lutan, 2003). Untuk itu guru penjas 
harus memiliki sikap dan perilaku yang mampu mengembangkan self esteem peserta didik melalui perkataan dan tindakan selama proses pembelajaran penjas yang termuat dalam program penjas yang sesuai dengan tingkat pertumbuhan dan perkembangan peserta didik.

"Program penjas yang baik akan memberikan kesempatan kepada siswa untuk mengembangkan kepercayaan diri, mengembangkan nilai-nilai pribadi melalui aktivitas jasmani baik secara perorangan maupun berkelompok" (Lutan, 1998). Bila tujuan itu tercapai, hal itu memungkinkan peserta didik untuk memperoleh dan menerapkan pengetahuan tentang aktivitas jasmani, pertumbuhan dan perkembangan, perkembangan estetika dan sosial, mengembangkan sikap positif, mengembangkan keterampilan sosial untuk berkomunikasi secara efektif dengan orang lain (Lutan, 1998).
Kesempatan dan manfaat yang akan diperoleh peserta didik akan tercapai apabila guru penjas mampu bertindak sesuai dengan fungsi dan peranannya dalam mengembangkan potensi yang dimiliki peserta didik. Termasuk ketika berupaya meningkatkan self esteem pada diri peserta didik. Salah satu cara meningkatkan self esteem menurut Lutan (2003) adalah "Melalui komunikasi yang efektif". Indikator terpenting dari komunikasi yang efektif adalah berterus terang, mendengar, dan merasakan perasaan orang lain".

Guru yang baik harus berterus terang memberikan penilaian terhadap kemampuan peserta didik dengan menceritakan hal yang sesungguhnya dengan cara yang tidak membuat peserta didik semakin terpuruk. Misalnya guru harus menghindarkan kata-kata "kamu tidak bisa" kepada peserta didik, tetapi diutarakan dengan kata "belum bisa" ketika peserta didik belum mampu melaksanakan tugas gerak sesuai dengan harapan guru. Hal terpenting lagi adalah guru 
tetap memiliki pendirian yang konsisten terhadap ucapan dan perilakunya. Guru penjas yang baik adalah guru yang mau mendengar dan memperhatikan segala hal yang diutarakan peserta didik dalam rangka perbaikan proses pembelajaran. Guru penjas yang baik pun adalah orang yang mampu menerima perasaan orang lain, termasuk perasaan peserta didik.

Ketiga indikator yang termuat dalam komunikasi yang efektif sesungguhnya merupakan proses pemberian feedback atau umpan balik yang dilakukan guru selama proses pembelajaran. $\mathrm{Hal}$ itu dilakukan tidak saja dalam kegiatan belajar mengajar di kelas atau di lapangan melainkan ketika aktivitas belajar telah selesai dilaksanakan. Misalnya di sela-sela waktu istirahat, guru biasanya mengingatkan peserta didik untuk terus berlatih atau aktif dalam kegiatan ekstrakurikuler sesuai dengan cabang olahraga yang dipilih peserta didik. Secara tidak langsung, peristiwa komunikasi tersebut dapat menjadi umpan balik (feedback) bagi peserta didik untuk selalu diingatkan akan keharusannya berlatih sekaligus termotivasi karena adanya perhatian dari gurunya. Seperti halnya dalam konteks kepelatihan, peserta didik sebagai atlet membutuhkan umpan balik. Harsono (1988, hlm.87) mengemukakan "Atlet membutuhkan umpan balik untuk mengetahui bagaimana hasil-hasil latihannya, dan apa yang masih harus diperhatikan dan ditekankan dalam latihan-latihan untuk kemajuan prestasinya".

Secara umum feedback terbagi ke dalam dua jenis yaitu intrinsic feedback dan extrinsic feedback (Apruebo, 2005). Intrinsic feedback atau umpan balik intrinsik terkait dengan penilaian terhadap dirinya sendiri, tentang sikap atau perilaku yang telah dilakukannya, tentang kemampuan yang telah ditunjukkannya. Misalnya dalam melakukan tugas gerak, apakah aktivitas yang dilakukan sudah sesuai dengan yang diinstruksikan guru, apakah merasa nyaman 
dengan alat bantu yang digunakan, atau menilai bahwa rangkaian gerakan senam telah sesuai dengan urutan yang harus dilakukan. Sedangkan extrinsic feedback adalah umpan balik yang berasal dari luar dirinya. Misalnya koreksi dari guru penjas atas gerakan yang sudah dilakukan, cemoohan rekan karena salah memberikan umpan ketika bermain bola, atau dari lingkungan sekitar seperti cuaca yang terlalu panas sehingga mengharuskannya sering beristirahat di tempat yang teduh.

Fungsi feedback adalah memberikan motivasi, reinforcement (Harsono, 1988, hlm. 89) atau punishment (Lutan, 1998). Menurut Apruebo (2005, hlm. 100), "Reinforcement means any event that increase the probability that a particular response will reoccur under similar consequences". Reinforcement maksudnya adalah pemberian penguatan atas kejadian atau aktivitas yang telah dilaksanakan sehingga aktivitas tersebut tetap mampu dipertahankan atau memberikan respons yang serupa dan pada aktivitas berikutnya dapat meningkat lagi. Dalam hal pemberian reinforcement Weinberg dan Gould (1995, hlm. 137) mengemukakan "Reinforcement is the use of reward and punishment that increase or decrease the likelihood of similar response occurring in the future". Bahwa reinforcement dapat menggunakan penghargaan atau hukuman yang mungkin sekali dapat meningkatkan atau menurunkan respons serupa yang terjadi pada masa berikutnya. Penghargaan tidak selalu dalam bentuk benda sebagai hadiah, tetapi dapat melalui ungkapan-ungkapan. Contohnya ungkapan guru penjas yang mengatakan "Lemparan kamu sudah bagus, coba lempar ke sasaran yang lebih jauh!" Sedangkan punishment lebih bersifat memberikan penilaian buruk atas apa yang dilakukan oleh peserta didik. Misalnya pada ungkapan "Lemparan kamu ngawur, jangan asal lempar saja!" 
Umpan balik dapat diberikan dalam beberapa jenis, misalnya seperti knowledge of result, objective measures, self monitoring, snap judgement, video playback (Butler, 1996 dalam Apruebo, 2005). Jenis umpan balik yang lain dikemukakan oleh Suherman (1998, hlm. 126) yaitu umpan balik positif, umpan balik netral, dan umpan balik negatif. Ketiga jenis umpan balik ini paling sering dijumpai dalam kegiatan belajar mengajar penjas yang bersifat praktik di lapangan dan lebih mudah dilakukan oleh guru. Umpan balik positif ditandai dengan ungkapan guru seperti bagus, hebat, dan pintar. Umpan balik netral diungkapkan guru dengan tidak merujuk kepada kesalahan tugas gerak yang dilakukan seorang peserta didik akan tetapi mengingatkan kepada semua peserta didik. Misalnya dalam belajar menyundul bola, guru mengatakan buka mata untuk melihat arah bola. Umpan balik negatif adalah kebalikan dari umpan balik positif. Pada umumnya umpan balik negatif diajurkan secara implisit atau tidak langsung, misalnya pada ungkapan guru "Kamu tidak becus mengoper bola" sebaiknya diungkapkan "Jangan hanya didorong, lempar bola itu dengan kuat agar sampai ke teman kamu!". Helmy Firmansyah dalam penelitiannya menyebutkan bahwa terdapat interaksi antara gaya mengajar dan umpan balik terhadap keterampilan gerak dasar.

Pemberian jenis umpan balik harus disesuaikan dengan kebutuhan peserta didik. Kebutuhan peserta didik terkait dengan tingkat perkembangan psikososial peserta didik. Pada perkembangan peserta didik di masa remaja yang terkadang memiliki keinginan diperhatikan secara berlebihan atau bahkan ingin diberikan kebebasan seluasluasnya, guru harus berhati-hati memberikan umpan balik untuk perbaikan atau koreksi atas kekeliruan yang dilakukan peserta didik. Kekurangsesuaian jenis umpan balik yang diberikan akan berdampak kepada perasaan tidak 


\section{Didaktik : Jurnal Pendidikan Guru Sekolah Dasar, ISSN : 24775673 \\ Sekolah Tinggi Keguruan dan IImu Pendidikan Subang Volume IV Nomor 1, Juli 2018}

enak, pesimistis, tidak memiliki motivasi, atau tidak memiliki harga diri karena selalu mendapat teguran guru. Untuk itu karakteristik peserta didik harus mendapat perhatian penting ketika guru akan memberikan umpan balik. Sebuah penelitian yang dilakukan oleh Didin Budiman (2009) tentang pemberian umpan balik menghasilkan tiga aspek penting yang harus diketahui oleh guru penjas dalam pemberian umpan balik, yaitu: (1) Pemberian umpan balik positif memberikan pengaruh yang signifikan pada pengembangan konsep diri yang positif pada siswa sekolah dasar, (2) Pemberian umpan balik netral tidak memberikan pengaruh yang signifikan pada pengembangan konsep diri yang positif pada siswa sekolah dasar, dan (3) pemberian umpan balik positif lebih baik daripada pemberian umpan balik netral.

Karakteristik siswa SMP (1316 tahun) tergolong ke dalam masa remaja awal. "Karakteristik umum masa remaja adalah memandang sesuatu hal dari yang bersifat subyektif menuju ke arah yang obyektif" (Makmun, 1995). Lebih lanjut Makmun mengemukakan bahwa usia remaja pada masa anak sekolah umumnya dituntut untuk dapat mengerjakan atau menyelesaikan sesuatu dengan baik dan sempurna. Kemampuan melaksanakan tugas merupakan kepercayaan atas kecakapannya. Kalau tidak, maka akan timbul perasaan rendah diri (inferiority) atau self esteem yang rendah sekali yang akan dibawanya pada taraf perkembangan selanjutnya. Masa remaja sudah menunjukkan kepada proses pemenuhan kebutuhan pada tahap penghargaan dan perwujudan diri (Teori Kebutuhan Maslow), dan sudah menunjukkan arah kecenderungan tertentu yang akan mewarnai pola dasar kepribadiannya (Soesilowindradini, 1995)

Dalam penelitian ini peneliti juga ingin mengkaji mengenai bagaimana peran gender dalam pemberian umpan balik dan self 
esteem. Hal ini sangat menarik karena berdasarkan pada hipotesis intensifikasi gender (gender intensification hypothesis) bahwa perbedaan psikologis dan perilaku antara laki-laki dan perempuan menjadi semakin besar pada masa remaja awal karena meningkatnya tekanan sosialisasi untuk menyesuaikan diri pada peran gender maskulin dan feminim. Dimana masa remaja awal adalah masa usia sekolah menengah pertama. Peneliti ingin melihat apakah ada perbedaan pada peserta didik laki-laki dan perempuan setelah diberikan pemberian umpan balik dan bagaimana pengaruhnya terhadap self esteem peserta didik yang tentunya berdasarkan gender.

\section{B. Metode Penelitian}

Metode yang digunakan dalam penelitian adalah metode eksperimen. bahwa kegiatan percobaan (eksperimen) yang dimaksud adalah penerapan umpan balik positif dan umpan balik netral. Sedangkan hasil yang diharapkan adalah meningkatnya self esteem pada peserta didik SMP.

\section{Populasi dan Sampel}

Populasi dalam penelitian ini adalah peserta didik SMP Lab UPI Bandung kelas VII yang terdiri dari 6 kelas yaitu kelas $A, B, C, D, E$ dan F. Berdasarkan hasil pengundian sampel secara cluster random sampling, maka terdapat dua kelas yang terpilih menjadi sampel pada penelitian ini. Kelas yang menjadi kelompok eksperimen ialah kelas VII D yang terdiri dari 29 peserta didik dan kelas VII $E$ menjadi kelompok kontrol yang terdiri dari 28 peserta didik. Sehingga jumlah sampel keseluruhan pada penelitian ini sebanyak 57 peserta didik.

\section{Desain dan Prosedur}

Desain yang digunakan adalah desain faktorial $2 \times 2$. Penelitian ini dilaksanakan selama 8 kali pertemuan yang dilaksanakan setiap 1 kali dalam seminggu, jadi penelitian dilakukan selama 2 bulan. 


\section{Instrumen Penelitian}

Instrumen adalah suatu alat yang digunakan untuk mengukur fenomena alam maupun sosial yang diamati. Sugiyono (2009:102). Adapun instrumen yang digunakan dalam penelitian ini adalah angket. Pada penelitian ini, angket yang digunakan merupakan adopsi dari Self Esteem Rating Scale (SERS) yang dikembangkan oleh Nugent \& Thomas (1993). Validitas dan reliabilitas dari SERS ini sudah di uji. Pengujian validitas intrumen ini telah diteliti oleh Nugent (2004) dalam penelitian yang berjudul ' $A$ Validity Study of Two Forms of the Self-Esteem Rating Scale'. Angket SERS ini digunakan dalam penilaian klinis pada self esteem. Nugent \& Thomas (1993) dalam Fischer and Corcoran (2000, hlm. 690) memaparkan reliabilitas dari SERS, yaitu: 'The SERS has excellent internal consistency, with an alpha of 0.97. The standard error of measurement was 5.67. Data on stability were not reported'.

\section{Hasil Penelitian dan \\ Pembahasan}

\section{Hasil Penelitian}

Langkah-langkah yang ditempuh dalam pengolahan dan analisis data adalah sebagai berikut:

\section{a. Uji Prasarat}

Berdasarkan hasil analisis diketahui bahwa sebaran data self esteem peserta didik SMP berdistribusi normal.

Tabel 1: Data Hasil Tes Normalitas

Tests of Normality

\begin{tabular}{|l|r|r|r|r|r|r|}
\hline & \multicolumn{3}{|c|}{ Kolmogorov-Smirnova $^{\text {S }}$} & \multicolumn{3}{|c|}{ Shapiro-Wilk } \\
\cline { 2 - 7 } & Statistic & \multicolumn{1}{c|}{ Df } & \multicolumn{1}{c|}{ Sig. } & Statistic & \multicolumn{1}{c|}{ df } & \multicolumn{1}{c|}{ Sig. } \\
\hline Post & .089 & 48 & $.200^{*}$ & .978 & 48 & .488 \\
Test & & & & & & \\
Pre & .068 & 48 & $.200^{*}$ & .985 & 48 & .808 \\
Test & & & & & & \\
\hline
\end{tabular}

${ }^{*}$. This is a lower bound of the true significance.

a. Lilliefors Significance Correction

Tabel 2: Hasil Test Homogenitas

Test of Homogeneity of Variances

\begin{tabular}{|l|r|r|r|r|}
\hline & \multicolumn{1}{|c|}{$\begin{array}{l}\text { Levene } \\
\text { Statistic }\end{array}$} & \multicolumn{1}{c|}{ df1 } & \multicolumn{1}{c|}{ df2 } & \multicolumn{1}{c|}{ Sig. } \\
\hline Pre & 2.069 & 1 & 46 & .157 \\
Test & & & & \\
Post & .235 & 1 & 46 & .630 \\
Test & & & & \\
\hline
\end{tabular}




\section{b. Uji Hipotesis}

Berdasarkan analisis yang dilakukan diperoleh hasil sebagai berikut:

Tabel 3: Data Hasil Uji ANOVA

Tests of Between-Subjects Effects

Dependent Variable: Post Test Self Esteem

\begin{tabular}{|l|r|r|r|r|r|}
\hline Source & \multicolumn{1}{|c|}{$\begin{array}{c}\text { Type III } \\
\text { Sum of } \\
\text { Squares }\end{array}$} & \multicolumn{1}{c|}{ df } & \multicolumn{1}{c|}{$\begin{array}{c}\text { Mean } \\
\text { Square }\end{array}$} & \multicolumn{1}{c|}{ Sig. } & \\
\hline Corrected & $194.125^{\mathrm{a}}$ & 3 & 64.708 & 1.718 & .177 \\
Model & 252870.883 & 1 & 252870.88 & 6714.23 & .000 \\
Intercept & 176.139 & 1 & 176.139 & 4.677 & .036 \\
Feedback & 25.829 & 1 & 25.829 & .686 & .412 \\
Gender & 6.148 & 1 & 6.148 & .163 & .688 \\
Feedback * & 1657.125 & 44 & 37.662 & & \\
Gender & 263812.000 & 48 & & & \\
Error & 1851.250 & 47 & & & \\
Total & & & & & \\
Corrected & & & & & \\
Total & & & & & \\
\hline
\end{tabular}

a. $\mathrm{R}$ Squared $=.105$ (Adjusted $\mathrm{R}$ Squared $=.044$ )

Sesuai dengan tabel di atas diketahui hasil analisis data sebagai berikut:

Hasil perhitungan ANOVA pada variabel feedback menunjukan nilai signifikansi sebesar $0,036<0,05$ artinya Ho ditolak. Jadi kesimpulannya bahwa Terdapat pengaruh feedback yang signifikan terhadap self esteem. Skor self esteem siswa yang memperoleh feedback positif lebih besar daripada feedback netral.
Hasil perhitungan ANOVA pada variabel gender menunjukan nilai signifikansi sebesar 0,412 >0,05 artinya $\mathrm{Ho}$ di terima. Jadi kesimpulannya bahwa tidak terdapat pengaruh gender yang signifikan terhadap peningkatan self esteem. Hasil perhitungan ANOVA untuk interaksi menunjukan nilai signifikansi sebesar $0.688>0.05$ artinya $\mathrm{Ho}$ di terima. Jadi kesimpulannya bahwa tidak terdapat interaksi antara feedback dan gender terhadap peningkatan self esteem peserta didik SMP.

\section{Pembahasan}

a. Feedback memiliki pengaruh yang signifikan terhadap peningkatan self esteem peserta didik SMP.

Hasil perhitungan ANOVA pada variabel feedback menunjukan nilai signifikansi sebesar $0,036<0,05$ artinya $\mathrm{Ho}$ ditolak. Jadi kesimpulannya bahwa Terdapat pengaruh feedback yang signifikan terhadap self esteem. Skor self esteem siswa yang memperoleh feedback positif lebih 
besar daripada feedback netral. Fungsi umpan balik yang paling sering disajikan guru adalah sebagai alat untuk memotivasi peserta didik. Dalam ungkapan yang singkat Rink (1985, hlm. 35) mengemukakan "Feedback often serves as motivational function". Ungkapan yang sama dikemukakan oleh Rink (1985, hlm. 34), "Feedback serve three functions: (1) informing, (2) reinforcing, and (3) motivating". Meskipun demikian guru harus memperhatikan dua hal ketika memberikan umpan balik, yaitu: (1) Usia peserta didik, terkait dengan perkembangan moral, (2) Motivasi instrinsik dan ekstrinsik peserta didik. Pemberian feedback pada peserta didik yang diberikan secara continue pada pembelajaran penjas akan berdampak pada kesadaran peserta didik bahwa mereka memiliki kemampuan untuk melakukan gerakan yang diinstruksikan guru. Pemberian feedback membimbing peserta didik untuk melakukan apa yang seharusnya dilakukan ketika proses belajar mengajar penjas. Peserta didik akan merasa memiliki kemampuan untuk menyelesaikan tugas gerak dari guru yang memberikan feedback. Oleh sebab itu, keadaan ini akan menimbulkan self esteem peserta didik dapat meningkat.

\section{b. Gender tidak memiliki pengaruh yang signifikan terhadap peningkatan self esteem peserta didik SMP.}

Hasil perhitungan ANOVA pada variabel gender menunjukan nilai signifikansi sebesar 0,412> 0,05 artinya Ho di terima. Jadi kesimpulannya bahwa tidak terdapat pengaruh gender yang signifikan terhadap peningkatan self esteem. Hasil uji hipotesis menunjukan bahwa gender tidak berpengaruh secara signifikan terhadap peningkatan self esteem peserta didik SMP. Gender lebih menitikberatkan pada bagaimana perempuan dan laki-laki harus bertindak sesuai dengan jenis kelaminnya. Hal yang sama juga diungkapkan oleh Makarao (2009, hlm. 14) bahwa "gender berkaitan 
dengan peran dan tanggung jawab antara laki-laki dan perempuan dan ini ditentukan oleh nilai sosial budaya yang berkembang. Laki-laki dan perempuan memiliki perbedaan dalam cara berpikir serta dalam memecahkan masalah. Hal ini dapat dipahami karena struktur otak perempuan dan laki-laki berbeda. Hal ini sesuai dengan pernyataan Makarao (2009, hlm. 60) yang menyatakan bahwa "perbedaan perempuan dan laki-laki diantaranya dalam struktur fisik, organ reproduksi, cara berpikir dan dalam memecahkan masalah". Self esteem bisa dibentuk dan ditumbuhkembangkan yang tentunya dipengaruhi oleh beberapa faktor. Lutan (2003, hlm. 15) mengemukakan faktor-faktor yang mempengaruhi pertumbuhan self esteem yaitu sebagai berikut: Sumber utama bagi pengembangan self esteem adalah diri anda sendiri. Kita dapat mempertinggi atau memperendah self esteem sesuai dengan perasaan kita sendiri. Seseorang yang sehat self esteemnya ditandai oleh beberapa ciri diantaranya adalah Selalu memberi dorongan, motivasi kepada diri sendiri, Selalu memandang pada apa yang dikerjakan dan pada apa yang telah dilakukan.

\section{c. Tidak terdapat interaksi antara} feedback dan gender pada peningkatan self esteem peserta didik SMP.

Hasil perhitungan ANOVA untuk interaksi menunjukan nilai signifikansi sebesar $0.688>0.05$ artinya Ho di terima. Jadi kesimpulannya bahwa tidak terdapat interaksi antara feedback dan gender terhadap peningkatan self esteem peserta didik SMP. Pemberian feedback, baik positif maupun netral tidak memberikan pengaruh positif yang signifikan terhadap self esteem peserta didik SMP. Sedangkan gender baik putra maupun putri tidak memberikan pengaruh yang signifikan terhadap self esteem peserta didik SMP. Feedback yang diberikan ketika pembelajaran baik feedback positif maupun netral dan gender belum secara bersama-sama mampu 
mempengaruhi self esteem peserta

didik SMP secara signifikan.

\section{Kesimpulan}

Berdasarkan hasil
pengolahan dan analisis data,
maka diperoleh jawaban
pertanyaan penelitian yang diajukan. Kesimpulan atas jawaban pertanyaan penelitian adalah sebagai berikut :

1. Feedback memiliki pengaruh yang signifikan terhadap peningkatan self esteem peserta didik SMP.

2. Gender tidak memiliki pengaruh yang signifikan terhadap peningkatan self esteem peserta didik SMP.

3. Tidak terdapat interaksi antara feedback dan gender terhadap peningkatan self esteem peserta didik SMP.

\section{DAFTAR PUSTAKA}

Allegrante, John. (2010). A Foundation For Contemporary Health Education Practice.

Apruebo, Roxel A. (2005). Sport Psychology. Manila: UST Publishing House.

Arikunto, Suharsimi (1993). Prosedur Penelitian Suatu
Pendekatan Praktek. Jakarta : Rineka Cipta.

Block dan Robin. (1993). www.ncbi.nlm.nih.gov/pubmen/ 8339703

Budiman, Didin. (2009). Portal Jurnal UPI. Bandung

Firmansyah, Helmy. (2011). Pengaruh Gaya Mengajar dan Umpan Balik Terhadap Keterampilan Gerak Dasar Senam. Portal Jurnal UPI. Bandung

Freankel, Jack R, dkk. (2012). How to Design and Evaluate Research in Education. New York: McGraw Hill. Children Moving. A Reflective Approach to Teaching Phyisical Education. California: Mayfield Publishing Company.

Harsono (1988). Coaching Dan Aspek-Aspek Psikologis Dalam Coaching. C.V. Tambak Kusuma.

KidsHealth (2006). Developing Your Child's Self-Esteem. Internet. http//kidshealth.org

Koka, Andrea. (2006). University of Tartu. Estonia.

Kusmaedi, Nurlan., Husdarta, J.S., Hidayat, Yusuf. (2004).

Pertumbuhan dan Perkembangan Sepanjang Rentang Kehidupan Konsep, Teori, dan Implikasi-Implikasi Timbal Balik Terhadap Penjas dan Olahraga. Bandung: FPOK UPI.

Lutan, Rusli (1988). Belajar Keterampilan Motorik, Pengantar Teori Dan Metode. Jakarta: Depdikbud Dirjen Dikti Proyek 
Lembaga Pendidikan Tenaga Kependidikan.

Lutan, Rusli. (1998). Perencanaan dan Strategi Pembelajaran Penjaskes. PPGK-2536 (Modul $1 \mathrm{~s} / \mathrm{d}$ 2). Jakarta: Depdikbud Dirjen Dikdasmen Direktorat Pendidikan Guru dan Tenaga Teknis Bagian Proyek Peningkatan Mutu Guru Penjaskes Setara D-II.

Lutan, Rusli. (2001). Asas-Asas Pendidikan Jasmani Pendekatan Pendidikan Gerak di Sekolah Dasar. Jakarta: Depdiknas Dirjen Dikdasmen Bekerja sama dengan Dirjen Olahraga.

Lutan, Rusli. (2003a). Self esteem: Landasan Kepribadian. Jakarta: Bagian Proyek Peningkatan Mutu Organisasi dan Tenaga Keolahragaan Dirjen Olahraga Depdiknas.

Lutan Rusli. (2003b). Self esteem Yang Sehat: Teknik Pengembangan. Jakarta: Bagian Proyek Peningkatan Mutu Organisasi dan Tenaga Keolahragaan Dirjen Olahraga Depdiknas.

Makmun, Abin S. (1995). Psikologi Kependidikan Perangkat Sistem Pengajaran. Bandung: PT Remaja Rosadakarya.

Mruk, JC. (2006). Self Esteem, Research, Theory and Practice. United States: Maple Vail Book Manucfacturing Group.

Rink, Judith E. (1985). Teaching Physical Education for Learning. ST. Louis: Times Mirror/Mosby.
Santrock, WJ. (2002). Life Span Development (edisi keenam). Jakarta: Erlangga.

Santrock. (2007). Remaja. Erlangga

Soesilowindradini. (ttn). Psikologi Perkembangan (Masa Remaja). Surabaya: Usaha Nasional.

Sudjana, Nana dan Ibrahim. (2001). Penelitian dan Penilaian Pendidikan. Bandung: Sinar Baru Algesindo.

Sugiyanto dan Sudjarwo. (1992). Materi Pokok Perkembangan dan Belajar Gerak Buku I Modul 1-6. Jakarta: Depdikbud Proyek Penataran Guru SD Setara DII.

Weinberg, Roberts S, dan Gould, Daniel. (1995). Foundations of Sport and Exercise Psychology. USA: Human Kinetics.

W. R. Nugent, and J. W. Thomas (1993). Validation of the SelfEsteem Rating Scale. Research on Social Work Practice. (3) 